\title{
A Complete Ration Composed of Concentrates and Sugareane Bagasse vs. a Conventional Ration of Pangolagrass and Supplemental Concentrates for Milk Production
}

\author{
Paul F. Randel, Manuel Soldevila, and Blas Salas ${ }^{1}$
}

\section{INTRODUCTION}

There is considerable interest in feeding complete rations composed of concentrates mixed with some source of fiber to lactating dairy cows. Satisfactory results have been obtained with alfalfa or alfalfa-grass mixed hay $(9,10,13),{ }^{2}$ corn silage $(7,11)$, haylage $(2,7)$, corn cobs $(9,10)$, cottonseed hulls $(2,9,10)$, pineapple hay $(8)$, and pineapple bran $(8,14)$, serving as the source of fiber.

In a previous experiment in Puerto Rico, ground sugarcane bagasse was shown to be an excellent source of fiber for complete rations for dairy cows (12). The present experiment was conducted to continue this line of research by comparing a bagasse-concentrates ration and a conventional system of Pangolagrass grazing, plus supplemental concentrates for milk production.

\section{MATERIALS AND METHODS}

A continuous-type feeding trial was carried out at the Gurabo Substation from October 1966 to September 1967. Twenty-four grade Holstein cows that calved between October 1966 and January 1967 were incorporated into the experiment on the 6th day of lactation. The interval from the 6 th to the 35th day of lactation constituted a 30-day preliminary period, during which all animals received the control treatment. Animals were kept in the experiment only if they produced a minimum of 30 pounds of milk daily. The cows were then assigned randomly to one of the two treatments, until there were 12 assigned to each. A 205-day comparison period followed from the 36th to the 240th day of lactation.

The control treatment consisted of pasturing day and night on Pangolagrass (Digitaria decumbens Stent.), except for two daily trips to the milking

1 Associate Nutritionist, Lajas Substation; Associate Nutritionist, Agricultural Experiment Station in Río Piedras, P.R., and Graduate Student, Mayagüez Campus, University of Puerto Rico, respectively. The authors gratefully acknowledge the assistance of Mr. George E. Pringle, Head of the Agricultural Economics Department, for providing an estimate of pasture costs, and of Mr. Julio Llinás, Graduate Student, for attending the animals during part of the study.

2 Italic numbers in parentheses refer to Literature Cited, p. 176. 
parlor, located close to the pasture. A commercial concentrate mixture, fed at the rate of 1 pound for each 2 pounds of milk produced, was given in the milking parlor. The treatment under evaluation, hereafter referred to as the "experimental treatment", consisted of maintaining the cows day and night in four pens with concrete floors, where the complete ration was fed ad libitum. In order to teach the first cow in each pen to eat the complete ration, some chopped green grass was mixed with it during the first 2 or 3 days. Later, cows in each pen followed the earlier cow's example and began to consume the complete ration immediately. These cows walked a distance of about 1 kilometer round trip to the milking parlor, and received no feed during milking.

Two brands of commercial concentrate mixtures with closed formulas, pelleted and guaranteed to contain a minimum of 20-percent crude protein, were fed to the control cows during the experiment. Urea supplied not more than 5.9 percent of crude-protein equivalent in one of them, and not more than 4.5 percent in the other.

The complete ration was prepared at the Lajas Substation and contained the following ingredients: Ground shelled corn, 40.2 percent; ground sugarcane bagasse, 22.5 percent; cane molasses, 20 percent; soybean-oil meal, 10 percent; tunafish meal, 5 percent; dicalcium phosphate or bonemeal, 1 percent; salt 0.75 percent; sodium bicarbonate, 0.5 percent; and vitamin supplement, 0.05 percent. Both the corn and the bagasse were ground in a hammer mill to pass thru a 1/4-inch screen. The bagasse was obtained from Central Aguirre Sugar Co., Aguirre, P. R., in dried and briquetted form, with part of the pith removed. The vitamin supplement was supplied by Dawe's Laboratories Inc., Chicago, Ill., and contained 3,000,000 U.S.P. units of stabilized vitemin A, 200,000 I.C. units of vitamin D-3, and 10,000 I.U. of vitamin $\mathbf{E}$ per pound.

The pasture consisted of 15.5 cuerdas $^{3}$ of Pangolagrass divided equally into three fields which were grazed in rotation for 7 days each. The pasture was fertilized with three 500-pound applications of a 14-4-10 fertilizer in October, February, and June, and 1 ton of pulverized limestone per cuerda annually. No other animals were allowed into the area. The stocking rate was light and ample good green forage was always available. Tree shade and water were always available to the cows at pasture.

Monthly samples of the complete ration were taken for chemical analyses. Proximate composition was determined by A.O.A.C. procedures (1), calcium content by a combination of the methods reported by Grewlind $(3,4)$, and phosphorus content by an unpublished procedure developed by A. Riera and J. Rivera-Núñez of the Central Analytical Laboratory, Agricultural Experiment Station, in Río Piedras.

- A cuerda is equal to 0.9712 acre. 
The cows were milked daily at approximately 7:30 a.m. and 3:30 p.m. The milk-production recorded for the preliminary period (uncorrected for composition) was used as the independent variable in analyses of covariance of the data for milk production during the first 30 days of the comparison period, during the remaining 175 days of the comparison period, and during the total 205-day period. A completely randomized design was used.

One aliquot sample of the milk of each cow was taken on the 35th, 65th, 94th, 123rd, 152nd, 181st, 210th, and 240th days of lactation. Fat and protein contents were determined by the Babcock and Kjeldahl Methods, respectively (1); and solids-not-fat by the Golding Bead Method (6). Average values for the milk composition of each cow over the entire comparison period were calculated, and the unpaired $t$ test was used to determine the significance of differences between treatment means.

Each cow was weighed in the morning of the 6th, 36th, 66th, and 241st day of lactation. No feed or water was allowed for 16 hours before weighing. The significance of differences between treatment means in live-weight changes was determined by the unpaired $t$ test.

Consumption figures for both the commercial concentrate mixture and the experimental ration were recorded. The price of the former was determined by averaging the cost of the various lots purchased during the experiment. The cost of the complete ration was calculated from the average prices of the ingredients used, all purchased from commercial sources, with an additional charge of 40 cents per 100 pounds to cover the cost of the mixing operation. The cost of pasture per grazing-day was estimated by assuming a carrying capacity of one animal per cuerda (0.9712 acre), and computing the total cost of maintaining a cuerda of Pangolagrass in the Gurabo area. Due allowance was made for the costs of labor, materials, taxes, insurance, interest on capital investment, land use, and depreciation. The milk produced was sold at $163 / 4$ cents per U.S. quart $(\$ 7.80$ per 100 pounds) regardless of its fat content.

\section{RESULTS AND DISCUSSION}

During the preliminary period the cows assigned to the control group produced an average of 42.9 pounds of milk and ate 23.1 pounds of commercial concentrates daily (tables 1 and 2). The corresponding figures for the animals on the experimental treatment, hereafter referred to as the "experimental cows," were $\mathbf{4 0 . 1}$ and 21.8 pounds, respectively.

The data from the first 30 days of the comparison period were analyzed separately in order to study the response to the two treatments at this critical phase of peak lactation. From the 36 th to the 65 th day of lactation the control cows averaged 43.8 pounds of milk daily, and consumed 21.9 pounds of commercial concentrates, which complies exactly with the planned 
TABLE 1.-Daily milk production and average composition for cows on experiment

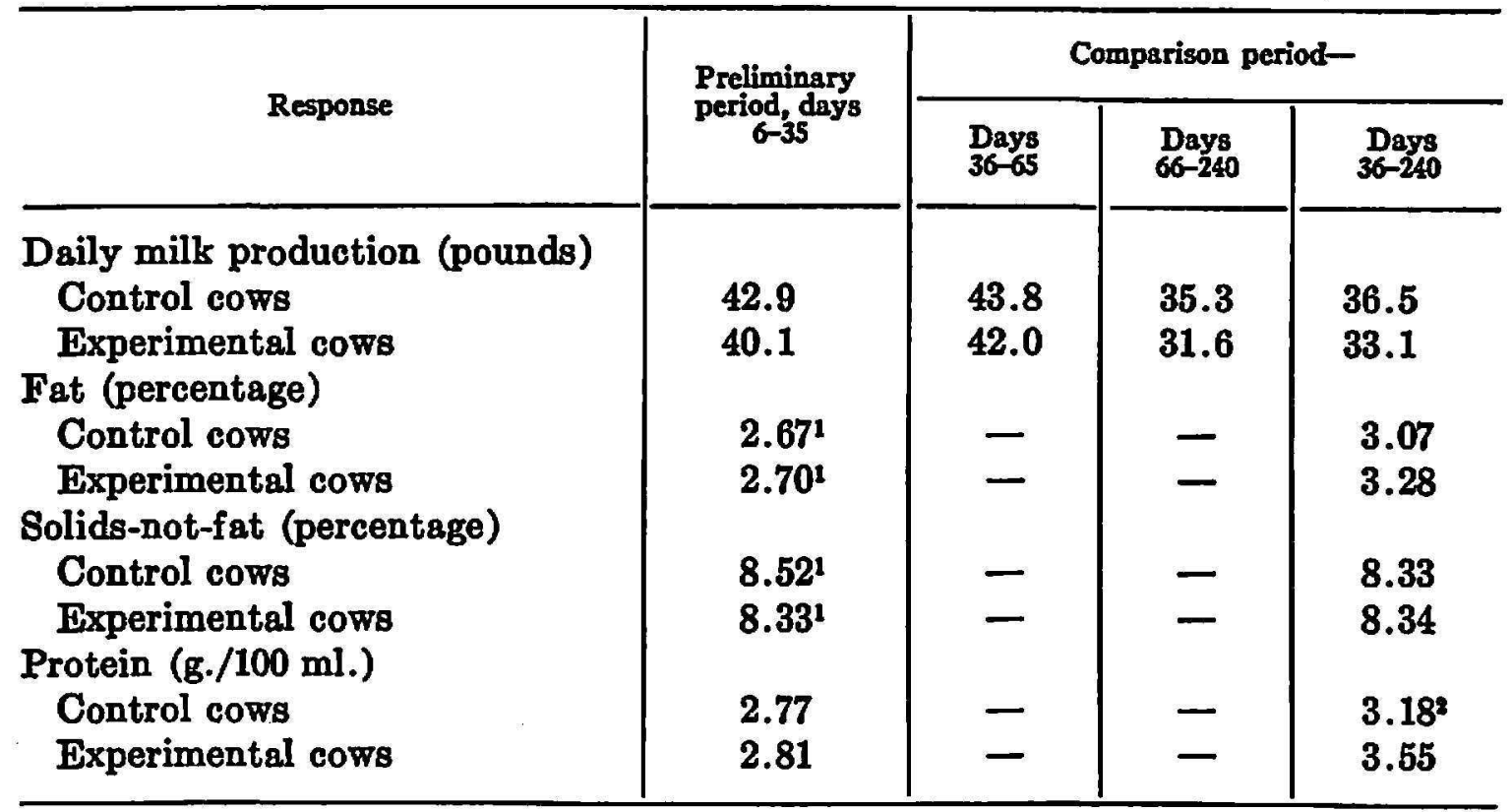

1 Based on data from 9 cows.

2 Difference between treatments highly significant $(P<.01)$.

TABLE 2.-Daily feed consumption by and costs for cows on experiment

\begin{tabular}{l|c|c}
\hline Consumption or cost & $\begin{array}{c}\text { Control } \\
\text { treatment }\end{array}$ & $\begin{array}{c}\text { Experimental } \\
\text { treatment }\end{array}$ \\
\hline
\end{tabular}

Preliminary and parts of comparison period

Commercial concentrates:

Consumption, days 6-35 (pounds)

Consumption, days 36-65 (pounds)

Consumption, days 66-240 (pounds)

\begin{tabular}{l|c} 
& \\
23.1 & 21.8 \\
21.9 & - \\
17.9 & -
\end{tabular}

Entire comparison period

Commercial concentrates:

Consumption, days 36-240 (pounds)

Cost per 100 pounds (dollars)

Cost per cow (dollars)

Pasture cost per cow (dollars)

Complete ration:

Consumption, days 36-240 (pounds)

Cost per 100 pounds (dollars)

Cost per cow (dollars)

Total feed costs per cow (dollars)

Gross income from milk per cow (dollars)

Return above feed costs per cow (dollars)

Feed costs per 100 pounds of milk (dollars)

\begin{tabular}{c|c}
18.5 & \\
4.41 & - \\
.82 & - \\
.34 & - \\
& - \\
- & \\
- & 36.1 \\
- & 3.58 \\
1.16 & 1.29 \\
2.85 & 1.29 \\
1.69 & 2.58 \\
3.18 & 1.29 \\
& 3.90
\end{tabular}


2:1 ratio. During this same 30-day period the experimental cows produced 42.0 pounds of milk daily. Unfortunately, the feed-consumption data for this group cannot be separated into different phases during the comparison period, because the phases of the three cows in a given pen did not coincide. With covariance adjustment for production during the preliminary period, the difference between treatments in average milk production during the first 30 days of the comparison period was not significant.

During the remaining 175 days of the comparison period the control cows averaged 35.3 pounds and the experimental cows 31.6 pounds of milk daily. One of the experimental cows died suddenly of undetermined causes only 10 days before the end of the experiment. The missing production data for this cow were estimated by extrapolating the curve representing her monthly decline in production. With covariance adjustment for production during the preliminary period, the difference between treatments in milk production during the final 175 days of the comparison period also proved to be nonsignificant. Thus the relative milk-production responses at peak lactation and during declining lactation were not notably different between treatments.

Over the full 205 days of the comparison period the control cows consumed an average of $\mathbf{1 8 . 5}$ pounds of commercial concentrates and produced 36.5 pounds of milk, daily. The experimental cows consumed an average of 36.1 pounds of complete ration and produced 33.1 pounds of milk, daily. Thus these 12 experimental cows required an average of 1.09 pounds of complete ration per pound of milk produced. This figure varied among the four pens from 0.97 to 1.22 . The difference in milk production between treatments was not significant, as shown by covariance analysis with adjustment for milk production during the preliminary period.

The average composition of the milk produced by the cows of both groups during the preliminary period was approximately the same (table 1). The figures for milk fat and solids-not-fat are based on data from only nine cows in each group, because excessively high fat content was obtained from the samples of the remaining cows and these were eliminated. The data on solids-not-fat from the same samples were eliminated, since, by the method used, these depend upon the fat percentage. No unreasonable values were observed for milk protein content, which probably reflects the lesser sensitivity of milk protein than of milk fat to faulty sampling techniques (5).

Of the 168 milk samples which should have been obtained during the comparison period, 18 were not collected as scheduled and 1 was missed from the cow that died. In addition, 13 excessively high milk fat and the corresponding solids-not-fat determinations were deleted. Thus the milk composition results must be viewed with reserve. The data finally available 
showed that the milk produced by the experimental cows was higher in all three components studied (table 1), though the difference between treatments was significant $(P<.01)$ only in the case of protein content $(3.55$ vs. $3.18 \mathrm{~g} . / 100 \mathrm{ml}$.). A higher protein content in the milk produced on a bagasse-concentrates complete ration than on a conventional ration was also found in a previous experiment (12). In neither study was any evidence found that the complete ration caused a decrease in milk fat content.

The average liveweights of the control and experimental cows 6 days after calving were 1,131 and 1,086 pounds, respectively. During the preliminary period the control and experimental cows lost an average of 4.21 and 2.35 pounds daily, respectively. In the comparison period, the respective average daily gains of the two groups in the same order were 1.91 and 2.12 pounds during the first 30 days; 0.25 and 0.33 pound during the remaining 175 days; and 0.52 and 0.56 pound over the entire period. The drastic weight losses by the control cows in the preliminary period, as well as the rapid gains by both groups in the first $\mathbf{3 0}$ days of the comparison period are difficult to explain. None of the mean differences between treatments in live-weight changes was statistically significant. In general, the data available for the various criteria of productive response do not provide evidence contrary to the null-hypothesis that the treatment under evaluation was not better than the control.

In a previous experiment, cows on a bagasse-concentrates complete ration showed higher daily averages for milk production (47.4 vs. 33.1 pounds) and live-weight gain ( 0.78 vs. 0.56 . pound) than the experimental cows of the present study (12). The average daily consumption of the complete ration was 7.5 pounds greater in the previous experiment, which likely provides part of the explanation. The average chemical composition of the complete rations of both the present and the previous experiment were rather similar (12), thus this does not explain the different responses. The complete ration used in the present experiment gave the following chemical analysis on the dry-matter basis: Crude protein, 15.3 percent; ether extract, 2.8 percent; crude fiber, 10.1 percent; nitrogen-free extract, 65.2 percent; ash, 6.6 percent; calcium, 1.0 percent; and phosphorus, 0.8 percent. The dry-matter content was 87.7 percent.

Possibly the experimental cows of the present study were adversely affected by certain nonnutritional factors. During the early part of the comparison period these cows were exposed to direct sunlight for several hours everyday. This stress was eventually eliminated by the use of a saran shade, but it probably exerted a detrimental effect during peak lactation. After being subjected to the experimental treatment for a while, several cows exhibited a moderate lameness. This condition seemed to occur because of mechanical injuries to the hooves of the animals by small stones, while going to and coming from the milking parlor. Sand was tried 
as bedding in the pens to make the lame animals more comfortable, but because of the humidity, several cases of foot rot developed. Subsequently, humid bagasse was tried, proving to be better than sand. However, bagasse attracted flies, produced objectionable odors, and made it hard to keep the animals clean. These reasons forced the elimination of bedding.

The cost of pasture was estimated at 34 cents per grazing day (table 2). The average cost of the commercial concentrate was $\$ 4.41$, and that of the complete ration $\$ 3.58$ per 100 pounds. Total daily feed costs per cow were lower, and gross daily income from milk produced and daily income above feed costs were higher under the control than under the experimental treatment by margins of 13,27 , and 40 cents, respectively. Daily income above feed costs varied among the four pens of experimental cows from $\$ 0.99$ to $\$ 1.60$ per animal. The feed costs involved in the production of 100 pounds of milk were estimated to be 72 cents higher under the experimental treatment (table 2).

Though the statistical significance of the differences between treatments in economic return could not be tested, the mean figures were decidedly in favor of the control. The unfavorable economic returns observed in the present experiment emphasize the fact that the complete ration is not advantageous unless high average levels of milk production (40 pounds per day or more) are obtained with it. Perhaps several of the experimental cows of the present study did not possess quite high enough inherent productive capacity, or perhaps the nonnutritional adversities cited above prevented their achieving an adequate level of production.

Routine microscopic examination of quarter samples of the milk of each cow (a regular herd practice), revealed that the incidence of presumptively infectious bacteria in one or more quarters was 62.5 and 56.4 percent in the control and in the experimental cows, respectively. Four interim cases of clinical mastitis occurred in the former and seven in the latter group. All cases responded to antibiotic therapy and apparently caused no long-term effects on milk production.

Delayed breeding was a generalized problem. At the end of the experiment only five control and six experimental cows were in calf. The cows of the control group which conceived required an average of 2.8 services, and those of the experimental group an average of 1.7 services per conception. One experimental cow aborted at about 4 months of gestation. Two cases of metritis or pyometra were encountered among the controls and four among the experimental cows.

\section{SUMMARY AND CONCLUSIONS}

Twenty-four grade Holstein cows, which averaged not less than 30 pounds of milk daily during a 30-day preliminary period were subjected to either of two treatments: 1 , The control treatment which consisted of 
grazing properly managed Pangolagrass supplemented with a commercial 20-percent crude protein concentrate mixture; and 2, the experimental treatment which consisted of confining the cows and feeding them ad libitum a 15.3-percent crude protein complete ration containing 22.5percent ground sugarcane bagasse and 77.5 percent concentrates, minerals, and vitamin supplement.

The average milk production of the control and experimental cows was 42.9 and 40.1 pounds, respectively, during the preliminary period. During the comparison period the corresponding figures were 43.8 and 42.0 pounds for the first 30 days (peak lactation), 35.3 and 31.6 pounds for the remaining 175 days (declining lactation), and 36.5 and 33.1 pounds for the entire 205 days. None of these differences between treatments was significant using covariance adjustment for milk production during the preliminary period. The experimental cows consumed an average of 36.1 pounds of complete ration daily and required 1.09 pounds of feed per pound of milk produced.

The average protein content of the milk produced by the experimental cows during the comparison period was significantly $(P<.01)$ higher than that of the control cows ( 3.55 vs. $3.18 \mathrm{~g} . / 100 \mathrm{ml}$.). The average milk-fat percentages were 3.07 and 3.28 , and the average milk solids-not-fat percentages were 8.33 and 8.34 under the control and experimental treatments, respectively. The control and experimental cows gained live weight at the average rates of 0.52 and 0.56 pound per day, respectively.

Based on costs of $\$ 3.58$ and $\$ 4.41$ per 100 pounds for the complete ration and commercial concentrate, respectively, $\$ 0.34$ per head per grazing day, and $\$ 7.80$ income per 100 pounds of milk produced, the following economic estimates were made under the control and experimental treatments, respectively: Total daily feed costs per cow, $\$ 1.16$ and $\$ 1.29$; gross income from milk produced, $\$ 2.85$ and $\$ 2.58$; income from milk above feed costs, $\$ 1.69$ and $\$ 1.29$; and feed costs per 100 pounds of milk produced, $\$ 3.18$ and $\$ 3.90$.

With respect to the productive responses, no evidence was found contrary to the null-hypothesis that the treatment under evaluation was not better than the control. The mean figures for economic return were in favor of the control treatment, though no tests of statistical significance could be made with the data available. The results emphasize the indispensability of obtaining high average milk production (at least 40 pounds per cow daily) in order to make the complete ration economically competitive.

\section{RESUMEN Y CONCLUSIONES}

Veinticuatro vacas cruzadas con sangre Holstein, las cuales produjeron diariamente no menos de 30 libras de leche durante un periodo preliminar de 30 días, se sometieron a dos tratamientos: 1, El tratamiento testigo que 
consistió en pastoreo en yerba Pangola debidamente abonada, suplementada con un alimento comercial con un 20 por ciento de proteína bruta; y 2 , el tratamiento experimental que consistió en confinar las vacas y alimentarlas a discreción con una ración completa con un 22.5 por ciento de bagazo de caña molido y un $\mathbf{7 7 . 5}$ por ciento de concentrados, minerales y un suplemento vitamínico.

Durante el período preliminar, las vacas testigo y las que se sometieron a un tratamiento experimental produjeron diariamente un promedio de 42.9 y 40.1 libras de leche, respectivamente. Las cifras correspondientes al período de comparación fueron las siguientes: Durante los primeros 30 días de dicho período, cuando ocurría la lactación máxima, 43.8 y 42.0 libras; durante los siguientes $\mathbf{1 7 5}$ días, cuando ocurría un descenso en la lactación, 35.3 y 31.6 libras; y durante el período completo de los 205 días, 36.5 y 33.1 libras, respectivamente. Ninguna de las diferencias entre los tratamientos fue significativa estadísticamente al ajustar los datos mediante el análisis de covarianza, cuando se usaron los datos del período preliminar como variable independiente. Las vacas del grupo bajo el tratamiento experimental consumieron diariamente un promedio de 36.1 libras de la ración completa y necesitaron 1.09 libras de esta ración por cada libra de leche que produjeron.

El contenido promedio de proteína fue significativamente $(P<.01)$ mayor en la leche de las vacas bajo el tratamiento experimental que en la del tratamiento testigo ( 3.55 contra $3.18 \mathrm{~g}$. $/ 100 \mathrm{ml}$.). Los promedios en cuanto al porcentaje de grasa en la leche fueron 3.07 y 3.28 , y en cuanto a los sólidos-no-grasos 8.33 y 8.34, bajo los tratamientos testigo y experimental, respectivamente. La ganancia diaria promedio en peso vivo fue de 0.52 y 0.56 libra en las vacas de los grupos bajo los tratamientos testigo y experimental, respectivamente.

Basándose en un costo de $\$ 3.58$ y $\$ 4.41$ por cada 100 libras de la ración completa y la mezcla comercial de alimento concentrado, respectivamente, y $\$ 0.34$ por cabeza por día de pastoreo, y en un ingreso de $\$ 7.80$ por cada 100 libras de leche producida, se hicieron los siguientes estimados bajo los tratamientos testigo y experimental, respectivamente: Costo total de la alimentación por vaca por día, $\$ 1.16$ y $\$ 1.29$; ingreso diario por concepto de la leche producida, $\$ 2.85$ y $\$ 2.58$; ingreso después de deducir el costo de la alimentación, $\$ 1.69$ y $\$ 1.29$; y costo de la alimentación para producir 100 libras de leche, $\$ 3.18$ y $\$ 3.90$.

En cuanto a las respuestas de las vacas en términos de producción, no se encontró evidencia en contra de la hipótesis de nulidad, de que el tratamiento bajo evaluación no era superior al tratamiento testigo. A pesar de que no se obtuvieron suficientes datos sobre costos e ingresos para analizarse estadísticamente, los promedios favorecieron el tratamiento testigo. Los 
resultados enfatizan la indispensabilidad de obtener un alto promedio de producción de leche (por lo menos 40 libras diarias por vaca) para que la ración completa pueda competir en términos económicos.

\section{LITERATURE CITED}

1. Assoc. Offic. Agr. Chem., Official Methods of Analysis, 9th ed., Washington, D. C., 1960.

2. Benz, J. J., A comparison of complete feeds for lactating dairy cows, Feedsiuffs 38 (18): 111-2, 1966.

3. Grewlind, T., Flame photometry of calcium and magnesium in ashed plant materials; Resolution of anion interferences with ethylene-diaminetetraacetate, Chemist Analyst 50: 40-3, 1961.

4. Grewlind, T., An extraction procedure for the determination of total calcium, magnesium, and potassium in plant tissues, $J$. Agr. Food Chem, 10: 138-40, 1962.

5. Gilmore, H. C., and Gaunt, S. N., Variations in percent of protein, milk fat, and solids-not-fat between milkings and during the milking process, $J$. Dairy Sci. 46: 680-5, 1963.

6. Golding, N. S., A new method for estimating total solids and solids-not-fat in milk and liquid milk products by hydrometric means, Wash. Agr. Exp. Sta. Bul. 650, 1964.

7. Johnson, P. L., Reed, A., and Olson, H. H., Comparison of roughage and protein sources in complete feeds for dairy cows, J. Dairy Sci. 60: 964, 1967.

8. Komkris, T., Stanley, R. W., and Morita, K., Effect of feeds contrining molasses fed separately and together with roughage on digestibility of rations, volatile fatty acids produced in the rumen, milk production, and milk constituents, $J$. Dairy Sci. 48: 714-9, 1965.

9. Leighton, R. E., and Rupel, I. W., Comparison of the feeding values of various low-roughage rations and normal ration for dairy cows, J. Dairy Sci. 47: 708, 1964.

10. McCoy, G. C., Thurmon, H. S., Olson, H. H., and Reed, A., Complete feed rations for lactating dairy cows, J. Dairy Sci. 49: 1058-63, 1966.

11. Muller, L. D., Harshbarger, K. E., and Oliver, E. F., Group feeding lactating dairy cows a complete feed mixture of corn silage and concentrates, $J$. Dairy Sci. 60: 965, 1967.

12. Randel, P. F., Feeding lactating dairy cows concentrates and sugarcane bagasse as compared with a conventional ration, J.Agr. Univ. P.R. 50 (4): 255-69, 1966.

13. Ronning, M., and Laben, R. C., Response of lactating cows to free-choice feeding of milled diets containing from 0 to $100 \%$ concentrates, $J$. Dairy Sci. 49: 1080$5,1966$.

14. Stanley, R. W., and Morita, K., Effect of frequency and method of feeding on performance of lactating dairy cattle, J. Dairy Sci. 50: 585-6, 1967. 